\title{
The Role of Waste Recycle by Banking System to Economic Empowerment in Indonesia: A Case of Study of Bank Sampah Matahari Madiun
}

\author{
Intan Muthoharoh \\ University of Darussalam Gontor \\ East Java, Indonesia \\ intanmuthoharoh621@gmail.com
}

\author{
Syamsuri \\ University of Darussalam Gontor \\ East Java, Indonesia \\ syamsurigontor@gmail.com
}

\begin{abstract}
Financial institutions in Indonesia are various. There is a cooperative Bank, the company and others. The Bank is a term that means to make withdrawals, borrowing and saving money. Views will be the strength of the role of financial institutions to society, the Bank got the role is higher than other financial institutions. In the matter of OJK, accounting for about 116 central banks stood in Indonesia. With regard to the foregoing, the author would like to examine a bank, but the bank is not making money as an object. This bank makes garbage or waste as an object. Here that make the place named "the waste management by banking system", because objects that are used for the transaction is not valuables, such as money, securities, jewelry, electronics or others. The object is not always considered an even value, the item is garbage. So anyone who wants to be a bank, don't need to have a lot of money and capital goods are valuable, but anyone who has junk, could become customers. The benefits that accrue to the bank system, it also saves the community in waste management where previously have neighbourhoods less effective and much happens the pollution. Top floor it, the author would like to discuss how "Bank Sampah Matahari Madiun" applied the system does it work and what are the products that have been managed. In order to introduce to the public over the multitude of benefits it brings when in an area that held the waste management by banking system. The methods used in this study is qualitative field by taking resources from the real place, books, articles and data from a source that is examined.
\end{abstract}

Keywords: Social Media, Constituent Interaction, Constituent Mobility, Governor General Election, Political Campaign

\section{INTRODUCTION}

See the full range of life problems that increasingly more and more, then every problem must be taken the solution. A day in the life-day, solution for the sake of a solution has been found, so even though it has many things that become problems of human life, this modern era remain comfortable in living the life.

In advancing the economy of the country, have not only seen from one side only. Existing financial institutions have not only evolved from banking only. However there have been many emerging industries which becomes the trigger and took part in donating to the economy of the community. Industry examples include: Homemade, craftsmen and "the waste recycle by banking system" as a new solution for social economic empowerment in Indonesia.

"The waste recycle by banking system" just as a term meaning the garbage processing system applied by the banking system, but still based on the principle of a high social care for the cleanliness of the environment, and as it turns out, the environment becomes contaminated things to be done as well.

The problems of environmental pollution that is now going on one of these is the problem of waste, growing bolder accumulate in number. Policy holder namely the Government is already addressing this issue, namely waste manage integrated, for example from household waste. To manage waste in an integrated, key is required, namely "sorting based on type". That is, sorts out the various types of waste into different places since its inception. If not, trash cans and garbage bags that contained a mixture of waste must be sorted afterwards, a process that is costly, difficult, dirty, and dangerous. Local governance and Department of City Cleanliness helps us sort out the garbage as fully as possible. For example, the Government provides different colored bins at strategic places for certain types of waste [1].

Solving the garbage the other solution, which appears to look very good and raises mutualism symbiosis relationship, is the establishment of the "the waste recycle by banking system". at a glance if we heard the term Bank, the Bank is a term which means "the place where we can make withdrawals, borrowing and saving money, but here the object used for the transaction is not valuable, but garbage. So anyone who wants to be a client of Bank, don't need to have a lot of money and capital goods worth only, but anyone who has junk, could become customers.

In the end, many consider that the establishment of the "the waste recycle by banking system" is the right solution in the settlement of the garbage that piled up in various places. Evident from the establishment has already begun to Litter banks. One of the Bank's standing and famous is "Matahari waste recycle by banking system" Winongo Madiun. The reason the author wanted to examine system applied in empowering local communities and environment Besides this place has just been awarded the adipura [2] award form, where it proved invaluable to superior and good.

\section{MethodolOGY}

This study was conducted in Matahari waste management by banking system in Madiun. This study used a qualitative approach [3]. Qualitative data collection aims to collect data and analyze and identify and explore its predecessor. Data can be analyzed through a constant process of coding and comparison, as well as the view of constructivist based approach to theory. Analyzing data interview with literature that will be used to integrate and to the development of the 
concept of thought and theory building [4]. By using the method of grounded theory, where the writing methods of discovery are not based on previous theory. Because it uses the concept of comparing the events that occurred in the field, combining category and recognize its characteristics, using sampling theory, but is not sure if the concept and the events there are in the same field [5].

In data retrieval, data collection can be done in a variety of settings, that is, the source and how. However, if seen from the source data. There are two parts [4]. that is primary Data. Data source obtained from the first source where a data generated [6]. Secondary data is data that is obtained from the primary data source of a second. How to apply to get more information about "this waste management and the concept of management. For the method of collecting data, this research uses three methods. That is the method of observation, interview and documentation [6]. The first is the observation [7]. How this is done by visiting the location of the source of the research directly. By taking the data exactly from the field without any tools [5]. In the method of this observation, researchers did a lot of observations by being thoroughly against the observed object [8]. The deployment will be done by observing the condition of Matahari waste bank and analyze the behavior of the sellers and buyers as well as the surrounding communities.

The second method is the interview [9]. The kind of observation is unstructrure interview, the mean it is not specific because researcher hasn't known what is the aspect inside [4]. This interview using direct questions and answers between researchers with the respondent or information to get information [10]. Some objects of research will be in the interview include: manager of Matahari waste management by banking system, society of winongo district, some clients of bank. And the excess that be found is getting many data from the first source, although have a plenty of emotional [11]. Hence it, by the basic of grounded theory, the kind of interview is deep interview, the mean it will be done by following the daily of respondent and entangling- self inside, until coming up the question spontaneous what the researcher see, listen and feel with respondent [7].

The next data collection method is a method of documentation. the variable in the method of data it is shaped books, newspapers, official website of Matahari waste management by banking system, agenda, notes and more. The type of method research is explorative and Descriptive method. It called as explorative is caused the researcher want to know the symptom or incident which happen in the field by unsystematic method because no hypothesis before [12]. Then it called as descriptive because it will be used for defining and summarizing the condition, situation and variable [7]. and it was used to describe the content of the concepts from the original source. So the role of the theory is not yet too needed because researchers only have to decipher a fact which happened in Matahari waste bank.

\section{RESULTS}

Nowadays, though many found the humans who do the damage, but there is still much that is constantly working to build the most improvement. Among other efforts such as replanting forests bare, arid land irrigation, creation of Wildlife over the number of animals that became extinct, even to repair management system.
Furthermore it has been found the best solution for tackling the waste is good for the environment, the economy and the social. "The waste recycle by banking system". is a place where Garbage in it there is a system that functions as a public Bank, but its object is garbage [13].

Department of the environment said that the garbage be built with the bank is strategy to build a caring community so that more friendly with garbage, on the other hand there are economic benefits directly from the trash. Because "The waste recycle by banking system" cannot stand on its own without any direct from the public so 4R (Reduce, Reuse, Recycle, Replace) benefits are felt not only in economics, but the development environment that is clean, green and healthy.

"The waste recycle by banking system" also can be a solution to achieve cleanliness and convenient settlements for its residents. With this pattern then the citizens other than being disciplined in managing waste also get additional revenue from the junks that their groups. It seems the idea as it also agreed by the Ministry of environment. Government agencies have a target to build 250 "the waste recycle by banking system" across the city in Indonesia. Minister of State for the environment that was as Balthasar Kambuaya also said that waste has become a serious threat that, if not managed properly. Do not close the possibility if the next few years Indonesia society lives with piles of trash in their neighborhood [14].

Indirectly "the waste recycle by banking system" was instrumental in reducing the impacts of climate change. As it known junk turns out also to be one of the factors increasing the amount of greenhouse gas emissions in the atmosphere, in addition to other human activities related to energy, forestry, agriculture and animal husbandry. Like if a ton of solid waste produces 50 pounds of methan gas, then trash can donate 8800 tonnes $\mathrm{CH} 4$ per day. for global warming. Although $\mathrm{CH} 4$ has a higher power, but scientists estimate the $\mathrm{CH} 4$ had the force 20 times greater than $\mathrm{CO} 2$ [15].

MOE issued data that every 1 ton of solid waste can produce $50 \mathrm{~kg}$ of methane gas. In addition, the population of Indonesia are on the rise, can be estimated by the year 2020 , the resulting Waste reaches 500 million $\mathrm{kg} /$ day or 190,000 tons/year. This means the resulting methane gas reached 9500 tons/year. In addition, the gas is dangerous if not well managed. Therefore, "the waste recycle by banking system" is a perfect solution for reducing the impact of environmental damage. On the other hand, the program makes a society accustomed to collect waste themselves rather than throw it in the vain [16].

For most people, the garbage is a problem. In fact, any time the garbage is growing and without getting to know a holiday because every being continuously produce garbage. Various methods have been done to address the problem of waste. Various methods have been done to address the problem of waste.

Seminars on a variety of environmental experts always advise and deliver his opinion about the problems of garbage. The Government is trying to devise a variety of ways, so that larger costs. But the waste problem has not been resolved, even also continued to damage the environment, cause health disorders, and consuming the sacrifice that not a few. 
Technically, the Bank's operational Waste similar to banks in General. It's just that in the process of the withdrawal of savings are only allowed three months. This function maintain the financial stability of the bank. Each head of household has a garbage bag and the right account number as customer rights tubs properly. Customer-owned garbage or depositors are labeled in order not to be confused with another client.

Then trash bags were stored in a walk-in storage bins in accordance with its type. In General, the Teller has the task of taking down and match all customer deposits in a great book called the parent book. The garbage has been collected periodically deposited to artisan junkyard. After that special officer will calculate its economical every trash customer savings. So the bank officer did not specify how the Junk value customers. And the most important is there is no limit on the weight of the garbage that savings account holders. So deposit waste into customers full rights [16].

"The waste recycle by banking system" only there is Indonesia and not found in any country in the world. Spearheaded by Bambang Suwerda, a Professor of Health Sciences and the environment. He had the idea of setting up a place because the garbage where he lived, there was a lot of diseases caused by environmental pollution. "The waste recycle by banking system" was named Gemah Ripah located in Yogyakarta, on 23 February 2008 [15].

The waste recycle by banking system was moving up the social principles, it has slowly become a glance of the community, as more of the day, the Bank produces a nominal Waste of money that is not unexpected. Initially, society downplayed the presence of the Bank because the Garbage is considered futile work and waste time. The garbage is only regarded as things that are not useful and does not have a value [15].

Slowly, the success of The waste recycle by banking system, namely Gemah Ripah in Bandegan Village, Bantul, Yogyakarta, ultimately inspire other regions. Because of the Garbage, the Bank had been established in 20 villages in Bantul, involving approximately 1000 family of residents. They also have the motto "Saving life of garbage, cleaner and better tomorrows". There is no doubt that The waste recycle by banking system into a garbage-handling solutions that had piled up. Especially in the area of Bantul received 350-400 tons of trash each day in landfills (TPA).

Bambang said that the movements of the Bank this garbage should be a joint movement in dealing with garbage because it could not if each individual moves themselves. Bambang had success changing the mindset of the people, that the processing of garbage is not vain and useless, since it's now been proven that formed approximately 250 junk bank in Indonesia. Indicates that many people are starting to agree actions [15].

In article 1 paragraph (2) of the regulation of the Minister of State for the environment of the Republic of Indonesia number 13 year 2012, about the implementation of the guidelines through The waste recycle by banking system has also explained that the definition of a Bank is a place of Waste sorting and waste collection can in the recycling or reuse that have economic value [17].

The Government also acknowledge that the existence of The waste recycle by banking system really help solve
Indonesia community solutions in the field of preservation of the environment and the economy. In the legislation said that the establishment of The waste recycle by banking system was the best way of resolving the problem of environmental pollution [18].

So that it can be known from here on, The waste recycle by banking system becomes the best solution in the settlement of the problem of environmental pollution. But if in terms of the economy, The waste recycle by banking system also has many benefits and the function value. Among other things, reduce the amount of unemployment by creating new jobs, creating new brand of creation waste that is considered useless things into something of value and produce many benefits.

Waste management system that implements the settlement of remittance amounts of waste into bodies that formed and agreed with the local people called The waste recycle by banking system. To accommodate the garbage that has value to the number of tubes economy and given time in Exchange for some money. This is one way of changing the behavior of the community so as not to throw waste into streams, ditches, burn by way of implementation of the strategy of the 3R (Reduce, Reuse and Recycle).

Many place as waste recycle by banking system that can utilize the proceeds from this transaction to a different assignment. There is nothing in the send to the factory/ dealer recycled, handmade, making methane gas which is used as a replacement fuel for gasoline and LPG gas, or composter [19].

Many people think that it's been unused has no economic value, finally, for people who have a high creative and optimistic thinking, this is a golden opportunity which cannot neglect. Then came the new policy in the development of the bank's trash along with the rule of legislation. finally, already successfully established thousands of waste recycle by banking system in Indonesia.

Then the procurement policy of the Government in the development of The waste recycle by banking system for environmental preservation efforts is the precisely. Because, if the ecosystem running smoothly without interfering with each other, will be creating a balanced life and aligned. As it says in the Law Number 23 year 1997 article 1 paragraph 4 which reads that the ecosystem is an element of the environment which is a unified and interrelated in creating balance, sustainability and productivity to the surrounding environment [20]

The experts and Scholars of economics began to keen on researching and analyzing the Development of waste recycle by banking system in General, the reason is generally, if system and the benefits of good and a lot of useful, then any bias in The waste recycle by banking system presume one of contributor even the world economy of the country.

\section{DISCUSSION}

At this time the discussion focused to Matahari waste recycle by banking system in Madiun. It was located in the Madiun Winongo, Manguharjo, Madiun. The area including the place producing a lot of garbage, in a single day can produce 91 tons of garbage that comes from dwelling house residents, suburban roadways, shops, markets, and so on. Therefore, in the vicinity there is also a Final Landfill (TPA). Winongo village, Manguharjo subdistrict, Regency Madiun 
including producing waste that much, in one day can produce 91 tons of garbage that comes from dwelling house residents, suburban roadways, shops, markets, and so on. In 2010, there was an extraordinary Occurrence that form the bulk of dengue makes some communities realize that their environment is not good and dangerous. Finally came the idea of a woman who spirited high social, caring environment and hearted, Ms. Siyam Sumartini s. Sos, M.SI, so her name was called, which until now the main Manager Matahari waste recycle by banking system

The idea of establishing the system, caused by concern the Manager aware of the community, especially the mothers to care for their environment, so they don't happen again the events. Although the idea was not accepted, the Manager remains adamant this environmental conservation program continues, because sure that the job is never a waste. All sorts of goodness and benefits more obtainable if every community care.

At the beginning of establishment, taking garbage performed at some point the location of the residence communities, makers of trash surround some place to garbage. Until now, public awareness began to rise so that they come bringing trash each for making a deposit in The waste recycle by banking system. The community came to the bank by bringing garbage bins, Each customer has an account.

On Matahari waste recycle by banking system, there are several bank administrators garbage, which recruited not from people with title. Because according to the Manager, the person is not required, but it works titled no maximum. As for the Executive Board, its members consist of the Manager, Secretary, Treasurer, Operating Divisions, worthy creations, are worth selling. The Bank's Executive Board to become a Matahari's employer, no special skills required in the areas of financial or secretary, but it takes just people who can afford the intention, and the consequences. The Bank's Executive Board, only required ten people only, it doesn't take much-a lot of people, than many but not optimal, it is better, a little mean but seriously, because basically, their working is as social working. It is like sorting, selecting something useful, juggle objects have no value, be worth selling. So it is not pursuing the target.

During standing, developing, to forward such The waste recycle by banking system right now, Matahari waste recycle by banking system almost never have constraint, even increasing every year. It used to be that concern for only about eight people, but now, The waste recycle by banking system is already three hundred more. So it shows the increasingly strong awareness of the environment.

Directions of activity of Matahari waste recycle by banking system is empowering the community economy, invites residents to care for the environment, engage citizens like saving, empowering communities in the recycle bins to dry into a variety of forms of craft and Recycle trash into compost moist.

Finally anyone who planted, then he will reap, in 2016 , The waste recycle by banking system in Madiun, named as Matahari waste recycle by banking system awarded sinovik top 99 from Minister of empowerment of State operators. From 2476 nominated in Indonesia, 99, who was taken from the community, the award directly from the Ministry of empowerment of State Operators

Now Matahari waste recycle by banking system not only deal with empowerment, but also making creation trash into unique items, such as bags, wallets, vases, lamps, clothes, etc. The price of the processed goods ranging from 3000 up to 300,000 rupiah. The products marketed by the employer of Matahari waste recycle by banking system, not only products from within, but it could also promote other waste products. If there are orders, Matahari waste recycle by banking system invites many co-workers, such as a smart sewing, or who had expertise in processing these items, so indirectly provide new jobs, for unemployment.

Transaction process that exists in Matahari waste recycle by banking system: the deal based on the schedule of harvest trash (Saturday and Sunday) and the selection of savings products. Here is a schematic process of depositing waste in Matahari waste management by banking system.

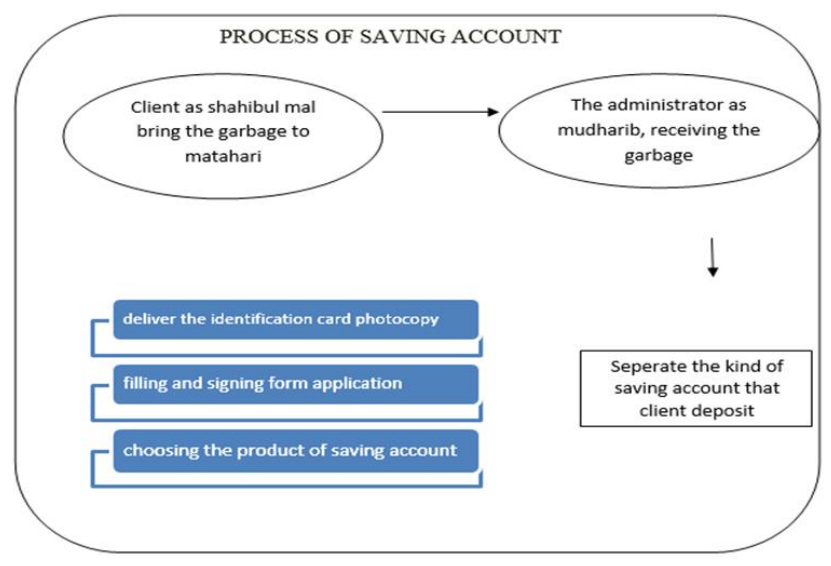

Figure 1. Transaction process in Matahari Waste Recycle

When compared to the condition that occurs in other areas, people throw away trash by issuing fee, but if you want to get the opposite, it is better to regulate smarter community life By laws by means bring their household garbage in garbage bank.

Based on the type of waste, garbage, household garbage is deposited to the Matahari waste recycle by banking system was divided into two types. Both are organic waste and garbage is inorganic [21]. Organic waste processed by way of a composter, and transformed into compost. If it becomes compost, then done weighing composting, then weighing after the official bank waste belongs to matahari waste recycle by banking system, and clients get the right form of money corresponding to the value of the agreed weigh.

Whereas inorganic trash, rubbish customer need only bring the bank to dry litter, garbage make a deposit to the Executive Board, then the administrators weigh the garbage, and the customer gets the money in accordance with the values already agreed. Waste inorganic garbage weighing results, by a trash sorted trash at the bank, was changed to handicrafts, or sold to a third party supplier, usually called junk.

As for the system of savings deposits, consisting of three systems, namely: education savings, Social Savings deposits and id fitri Savings. savings education, is in the open by the parents for his son, as a repository of school fees. Can be opened on behalf of the children in school. Because in this modern era, the number of household spending that makes 
parents sometimes forget and ignore the child's school fees. To anticipate it, Matahari waste recycle by banking system provides a solution for opening savings deposits of education for the child. As for the explanation of savings deposits of the feast is saving the customer should only be taken during the feast. It is intended, in order for communities in the face of Idul Fitri, though mediocre income, but can feel the happiness with the results the savings set aside specifically for the feast, so as not to mix with the primary requirement or the other secondary. Then the last one is the social savings. Social savings deposits which is aimed at someone who wants to move in the social field, but does not have enough money, then the customer can use her savings which from the beginning has already named a social savings, to perform the activities such socialctivities (such as Posyandu) elderly and toddlers.

\section{CONCLUSION}

Ultimately every human being in the world will certainly be confronted with problems to be found a solution. Similarly in Indonesia. One of the problems of society Indonesia is environmental pollution. Then each individual would think of what is the right solution in to handle it.

In 2008, one of the residents of Indonesia named Bambang Suwerda, a Professor of Health Sciences and the environment. He had the idea of setting up a place management because the garbage where he lived, there was a lot of diseases caused by environmental pollution. The Bank trash was named Gemah Ripah located in Yogyakarta.

The waste recycle by banking system was moving over the basic principles of social and environmental problems, as the solution turns out to be empowering the local community economy, as more of the day, the Bank produces a nominal Waste of money that big, though not but it is always evolving. The existence of any Garbage Bank initially considered paltry, pointless and a waste of time. Because Trash was simply a thing that is useless and has no value.

So that it can be known from here on, The waste recycle by banking system becomes the best solution in the problem solving environmental pollution and economics. in terms of Economic benefits include: reduces the amount of unemployment by creating new jobs, creating new creation and make waste that is considered useless things into something of value and produce many benefits.

\section{REFERENCES}

[1] Parker, Russ 2009, Krisis Pengelolahan Sampah, Jakarta: Bhuana Ilmu Popular.

[2] Balai Pustaka 1994 Indonesian Language Dictionary Jakarta: Balai Pustaka.

[3] Sugiyono, 2017, Metode Penelitian kuantitatif kualitatif R\&D Bandung: Alfabeta.

[4] Khan. Shahid. N. Qualitative Research Method: Grounded Theory. International Journal of Business and Management; Vol. 9, No. 11; 2014. p. 229

[5] Nazir, Moh 1988 Metode Penelitian, Jakarta; Ghalia Indonesia.

[6] Creswell, John. W. 2003 Research Design. Qualitative, Quantitative and mix methods approaches.

[7] Bungin. Burhan 2013 Metode Penelitian Sosial dan Ekonomi. Jakarta: Prenadamedia Grup.

[8] Teguh, Muhammad 2005 Metodologi Penelitian Ekonomi Teori dan Aplikasi. Jakarta: PT. Rajagrafindo Persada.

[9] Abdulloh, Boedi \& Saebani, Beni Ahmad 2014 Metodologi Ekonomi Islam Muamalah. Bandung: Pustaka Setia.

[10] Fajar, Mukti \& Achmad, Yuliatno 2013 Dualisme Penelitian Hukum Normatif \& Empiris, Yogyakarta: Pustaka Pelajar.

[11] Sarwono, Jonathan 2006 Methode Penelitian Kuantitatif dan Kualitatif. Yogyakarta: Graha Ilmu.

[12] Gulo. W. 2000 Metodologi Penelitian. Jakarta: Grasindo.

[13] Sucipto, Cecep Dani 2012 Teknologi pengolahan daur ulang sampah. Yogyakarta: Gosyen.

[14] The Ministry Of Environment Of The Republic Of Indonesia. Matching. Media communication environment. 1/2012

[15] Muthoharoh, Intan 2017 Praktek Bank Sampah Matahari Madiun menurut Hukum Islam. Thesis: University Darussalam Gontor.

[16] Bambang Wintoko. Panduan praktis mendirikan Bank Sampah. Jakarta: Pustaka Baru Press.

[17] Regulation of the Minister of environment of the Republic of Indonesia number 26 of the year 2012. About the technical instructions Special Allocation Funds Utilization Fields of environment the fiscal year 2013

[18] Law Number 23 year 1997 article 4 on the environment

[19] Alia Fajarwati August 21, 2014 Problem Sampah VS TPA Kedaulatan Rakyat.

[20] Mufid, Sofyan Anwar 2010 "Islam dan Ekologi Manusia", Paradigma Baru Komitmen danIntegritas Manusia dalam Ekosistemnya Refleksi Jawaban atas Tantangan Pemanasan GlobalDimensi Intelektual, Emosional dan Spiritual. Bandung: NUANSA.

[21] Interview of Management of Matahari Waste Management by Banking System. Sunday, 12 February 2017. 